\title{
EM TORNO DA VIDA DOS PEIXES
}

S. DE TOLEDO PIZA JR.

(Palestras proferidas durante a Somana de Piscicultura promovida pela 14. Cadeira (Zootecnia $2^{a}$. Cadeira), de 23 a 28 de Abril de 1951, em comemoração a $50^{\circ}$. aniversário da Escola Superior de Agricultura "Luiz de Queiroz", taquigrafadas por lsaias Rangel Nogueira e revistas pelo autor.)

\section{INDICE}

Anatomia dos peixes .. . . . . . . . . . . . . . . . . . . . 215

Fisiologia dos peixes e noções de sistemática . . . . . . . . 223

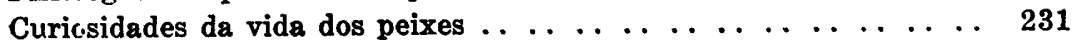




\section{ANATOMIA DOS PEIXES}

A Anatomia não é a Scientia amabilis, pois que é a ciência do sangue e do cadáver. Ciência pura, que nos põe em contacto com o objeto morto. Não tem portanto amabilidade alguma e pela sua natureza não pode despertar o interêsse dos ouvintes como os demais assuntos desta Semana de Piscicultura.

O estudo da Anatomia requer métodos especiais. Não é possível, no curto espaço de uma palestra, fazer um estudo metódico da organização dos Peixes. Teremos que apelar para a imaginação e procurar enxergar aquilo que apenas existe no nosso pensamento.

Suponhamos um peixe suspenso diante de nós. Examinemolo. $O$ que êle nos mostra em primeiro lugar é a pele. $O$ que é a pele do peixe ? Para melhor aprendermos seria bom comparála com a pele humana. Esta consta de dois estratos de tecidos. Um profundo, de natureza conjuntiva, bastante irrigado, a derme, e outro superficial, de células epiteliais vivas nas camadas profundas e que morrem à medida que se aproximam da periferia, a epiderme.

Estamos tôda hora perdendo pequeninas escamas pela superfície de nossa pele. Essas escamas são as células mortas que se desprendem. Em camadas sobrepostas, oferecem boa proteção âos estratos subjacentes. Glândulas sebáceas relacionadas com os pêlos e glândulas sudoríferas, são estruturas características da pele humana.

A pele do peixe também é formada de uma derme e uma epiderme. $\mathrm{Na}$ epiderme todos os elementos são vivos. As escamas encontradas na pele dos peixes são bem diferentes das nossas, que como vimos são mui pequeninas e mortas. As do peixe são grandes e estruturadas. Nascem da derme como uma papila conjuntiva, que se recobre de elementos epiteliais e cresce. A derme em alguns peixes fica pois constituindo o miolo da escama. Este é vascularizado e inervado, assegurando a nutrição e a sensibilidade da escama. Depois de completa, a escama exibe, ncsse caso, a estrutura de um dente. $E^{\prime}$ como se os peixes tivessem dentes na pele. Em outros peixes, parte da escama se ossifica ou corneifica. Nem pêlos, nem glândulas sebáceas ou sudoríferas se encontram na pele dos peixes. Seria mesmo absurdo querer que os peixes suassem. Glândulas mucosas, sim, existem em grande número, unicelulares umas, pluricelulares outras. 
Outra cousa que dá logo na vista quando se examina o peixe por fora, são os olhos. Em número de dois, situados lateralmente e bem desenvolvidos, diferem dos olhos humanos por um:ı porção de particularidades. Começa por não possuirem pálpebras nem glândulas lacrimais. Nós possuimos pálpebras para proteger os olhos e para sôbre êles esparramar as lagrimas, sem o que a visão seria indistinta. O peixe vive na água, está sempre com os olhos molhados e porisso não precisa nem de lá. grimas, nem de pálpebras. Também o ôlho do peixe apresenta uma outra particularidade: acha-se acomodado para a visão próxima. O ôlho humano é feito para ver ao longe e o do peixe para €nxergar de perto. Parece que haveria vantagem em enxergar os objetos distantes sem nenhum dispêndio de energia para a acomodação. Esta só se faria quando o objeto se aproximasse dos olhos e a imagem fugisse por isso da retina. Múscullos especiais entrariam então em atividade para modificar a curvatura do cristalino. No peixe, cujo cristalino é quase esférico, a acomodação se processa de outra maneira. Por intermédio de um cordão o cristalino pode ser deslocado mais para a frente ou mais para trás, repondo a imagem sôbre a retina quando ela tende a fugir pela aproximação do objeto ou pelo afastamento. $\mathrm{O}$ inecanismo de acomodação se compara à focalização nas màquinas fotográficas.

A aparente desvantagem de ter a vista focalizada para a visão próxima desaparece ao considerarmos que os peixes vivem em águas turvas, de pouco lhes valendo uma vista conformada para a visão distante. Êles que tratem, com a vista que tèm, de vigiar bem as imediações, que sempre haverá tempo para fugir aos seus inimigos.

Mais para a frente, vemos na cabeça do peixe, o nariz. Êste foi feito somente para cheirar. $O$ peixe cheira com una intensidade que fica muito distante da nossa insignificante capacidade olfatória. E' um animal cuja existência depende enormemente do olfato. $O$ cérebro do peixe possui um enorme lobo reservado ao sentido do olfato, que chega às vezes a formar um bulbo diretamente relacionado com o nariz, que é inteiramente forrado pela mucosa olfativa.

Vemos agora as nadadeiras. Os peixes mais primitivos tinham uma só nadadeira, que percorrendo a linha mediana, quase dava volta ao corpo, passando pela cauda. Com a evoluçãc, essa nadadeira se subdividiu em nadadeiras dorsais e ventrais. Adquiriram, além disso, os peixes, mais dois pares de nadadeiras : as peitorais e as abdominais. Esses órgãos varicim em número, mas podemos dizer que os peixes típicos possuem 1!ma nadadeira dorsal, uma caudal, uma ventral e dois pares de na- 
dadeiras laterais. Umas são propulsoras enquanto outras servem uara manter o corpo em equilíbrio. Evoluindo, as nadiadeiras pares acabaram por se converter nos membros dos Anfíbios, Répteis, Aves e Mamíferos. Os nossos braços e pernas originaram-se de nadadeiras de peixes. No embriāo, bem que os nossos membros recordam as primitivas nadadeiras. A nadadeira caudal é o que o peixe possui de melhor para a natação, embora as nadadeiras pares funcionem como verdadeiros remos. $O$ peixe é tanto melhor nadador quanto mais em forma de meia-lua for a nadadeira caudal e quanto mais separada do corpo poc uma parte fina e flexível. Com essa conformação, peixes há que acompanham com facilidade os mais velozes navios. Das nadadeiras laterais que o peixe possui, as torácicas têm posição permanente. Não se pode dizer o mesmo das nadadeiras abdominais, pois estas se deslocam, vindo muitas vezes situar-se na frente das torácicas.

4 bôca tem número variável de dentes de diversas furnas. Os peixes não são animais mastigadores. Os seus dentes são órgãos preensores. No desempenho dessa função muitas vezzes arraniam grandes postas de carne do corpo de suas vítimas, acompanhadas não raro de visceras inteiras.

Entremos agora, com os olhos da imaginação, pelo corpo do peixe a dentro.

Aparelho respiratório. Os peixes respiram por meio de brânquias. $\mathrm{Na}$ sua expressão mais simples, uma brânquia näo è mais do que uma pele modificada, muito permeável, recobrindo um tecido ricamente vascularizado. Os gases podem atravessar com facilidade o epitélio das brânquias e a parede dos capilares que as irrigam. A água entra pela bôca e sai pelas fendas em! que se encontram as brânquias. Essas fendas branquiais prodem ou näo ser protegidas por um opérculo. Havendo êste, os movimentos respiratórios podem ser notados com facilidade. $O$ peixe respira o oxigênio que se acha dissolvido na água e elimina o gás carbônico.

Abrindo-se o peixe logo se depara com o tubo digestivo. Em alguns peixes, principalmente nos carnívoros, êste é curto. $O$ esôfago, o estômago e os intestinos são mal delimitados. Com? - tubo digestivo é curto demais para a função que tem a desempenhar, a natureza dotou-o, em alguns casos, de uma membrany em espiral que o percorre no sentido longitudinal, aumentarido o trajeto dos alimentos que assim podem sofrer majs demoradamente a ação dos sucos digestivos. Em outros peixes - tubo digestivo é mais longo e deixa reconhecer com mais facilidace as suas diferentes partes. Como anexos, o fígadu e o pâncreas lá estão presentes. 


\section{FISIOLOGIA DOS PEIXES E NOÇŌES DE SISTEMÁTICA}

A Fisiologia trata do funcionamento dos órgãos. Vejamos em primeiro lugar como funciona a pele do Peixe. Esta, além da proteção reforçada pela escamação, desempenha diversos outros papéis. Assim, possui glândulas uni ou pluricelulares, produtoras de um muco que se espalha por todo o corpo, tornandoc liso e dêsse modo diminuindo o atrito com a água e facilitando a natação. A pele do peixe pode se constituir em órgão de defesa, recobrindo-se de espinhos. Quando o peixe nada pacificamente os espinhos se apresentam obliquamente dirigidos para trás. Ao defender-se, movimenta os espinhos para a frente, eriçando-se todo. Glândulas veneníferas abrindo-se na pele e relacionadas com espinhos, são de comum ocorrência. Muitos peixes abissais têm a pele iluminada por órgãos luminescentes, cuja significação não está ainda perfeitamente determinada.

Vejamos agora a função digestiva. A bôca do peixe é guarnecida de dentes que servem muito mais para a preensão e deglutição dos alimentos, do que para a mastigação. Em virtude do seu modo de vida o peixe não precisa de glândulas salivares uropriamente ditas. Para nós essas glândulas são de grande utilidade, ajudando a mastigação e a deglutição. Não podemos mastigar com a bôca sêca e muito menos engulir. Mas o peixe, vivendu na água, não precisa de órgãos para molhar a bôca ou para umedecer os alimentos. Os peixes que se alimentam de outros, engolem-nos com facilidade, pois aquêle muco que os reveste facilita a deglutição. Do ponto de vista da digestão proprianuente, a saliva não faz muita falta, nem mesmo para os animajs que a possuem. O fermento que contém é específico para (is hidratos de carbono (polissacarídeos). Em virtude da curta permanência dos alimentos na bôca, a saliva não tem iempo de desdobrá-los, o que não prejudica a digestão, porque ans intestinos outros sucos desempenharão aquêle papel.

$O$ estômago do peixe elabora um suco gástrico que possui pelo menos uma ênzima e o ácido clorídrico. A ênzima do estômago é da mesma natureza da que existe em outros animais e desernpenha o mesmo papel. E' conhecida por pepsina e é específica para o desdobramento das substâncias protêicas. Só atua em meio ácido, razão pela qual as glândulas gástricas sempre produzem o ácido clorídrico. O trabalho da pepsina não é completo. O desdobramento das proteinas não chega aos produtos finais, isto é, aos aminoácidos. Como o animal que serve de 
poucos se dividiu para dar o coração de três cavidades dos anfíbios, o qual por sua vez deu origem ao coração de quatro cavidades, tal como conhecemos nos répteis, nas aves e nos mamiferos

O encéfalo do peixe é ainda muito primitivo e porisso mesmo muitc diferente do nosso. $O$ cérebro é ainda muito rudimentar. Tanto o encéfalo do peixe como o humano originam-se da mesma maneira da ectoderme do embrião. Esta invagina-se, aprofundando-se para formar a goteira neural, cujos bordos se aproximam, se tocam e se fundem, dando assim origem a um tubo que percorre todo o corpo do organismo em formação, tal como se dá também conosco. O tubo neural que assim se origina logo se transforma numa corda nervosa que se aloja no canal formado pela sucessão das vértebras e que na cabeça se diJata para formar o encéfalo. À semelhança do que se verifica ni: homen, a rorção craniana do tubo se divide em três partes : encéfalo arterior, médio e posterior. $O$ encéfalo anterior dá origem ao telenréfalo e ao diencéfalo, o primeiro dos quais produz os hemisférios cerebrais ou cérebro propriamente dito; o do meio dá (rrigem ao mesencéfalo, do qual se desenvolvem os lúbos ou tu'Nérculos bigêminos (quadrigêminos no homem); o posterior da, tanto no peixe como no homem, para a frente o metencéfalo que logo se converte em cerebelo e para trás o mielencéfalo que se transforma em bulbo.

O cérebru propriamente dito do peixe é como dissemos muito primitivo. Os hemisférios possuem uma grande cavidade quase inteiramente ocupada pelo corpo estriado. O teto, que constitui " chamado arquipálio, é ainda desprovido d $\epsilon$ elementos nervosos. Sòmente mais tarde, em representantes de outras classes, é que " pálio se torna nervoso e se desenvolve para frirmar a capa cirzenta tão proeminente no homem. Este neopálio, como é chamado, cresce tanto, que precisa dobrar-se para caber na cajxa craniana. Dessas dobras resultam as circu'voluções cerebrais. Pela ausência do neopálio fica o peixe a trener.da distância de nós. O cérebro do peixe é essencialmente olfativo Anteriormenie, para o lado do nariz, prolonga-se para formar importantíssim: região, o bulbo olfativo, destinado a inervar a mucosa nasal. A natureza cuidou mais em fazer o peixe cheirar, do que pensar.

O diencétalo contribui para a formação de dois órgãos de secreção interra : a epífise ou órgão pineal, ná jarte lorsal a a hipifisc, na :ar te ventral. O hcrmônıo d sta úl' ma tem sido muito usado $\mathrm{em}$ piscicultura, para provocar a a $\because$ vá

A vesícula natatória, tão característica dos peixes, pode ser considerada como a primeira tentativa da natureza no sentido 
de fazer os pulmões. De fato, em alguns peixes a vesícula natatória pode funcionar à guisa de pulmoes. Em geral ela funciona como uma sorte de flutuador, que anula a ação da gravidade. O gás que nela se encontra não é o ar atmosférico. E' o produto da atividade de glândulas especiais que se encontram em suas paredes. A vesícula pode ter comunicação com o tubo digestivo por meio de um canal ou isolar-se mais ou menos completamente.

Externamente, de ambos os lados do corpo dos peixes encontramos as chamadas linhas laterais, que representam espécies de sulcos em cujo fundo existem órgãos sensoriais. A experiência demonstra que êsses órgãos não reagem às variações de temperatura da água e nem à presença de maior ou menor quantidade de oxigênio ou de substâncias químicas. Mas, reagem de modo sensível a ondas curtas transmitidas pelas águas. Numa das melhores opiniões, estas linhas ajudam os peixes a se equilibrar. Servem como uma espécie de radar, advertindo os peixes da aproximação de objetos.

Falemos agora do ouvido. Este é primitivo, como primitivo é n peixe. Se descermos da estrutura do nosso ouvido para a do peixe, iremos encontrar o início de uma história que chega até nós, passando pelos anfíbios e pelos répteis. $O$ ouvido do peixe conta-nos apenas o comêço da história do ouvido humano. O ouvido interno do homem, na mais simples expressão, encontrase já no peixe. O ouvido médio e o externo ainda não iniciaram c seu desenvolvimento. Dos canais semi-circulares, de que possuimus três, apenas dois estão presentes nos peixes. Alguns peixes mais evoluidos nesse sentido, já possuem os três. $O$ nosso romplicado caracol é representado por um simples esbôço, a lagena. Acontece que na lagena, no utrículo e no sáculo, bem como nas empôlas da base dos canais, há zonas sensoriais. Os peixes devem ser surdos à música, pois lhes falta o órgão de Corti. $\mathrm{O}$ ouvido dos peixes serve muito mais ao equilíbrio, que à audição. Em lugar daquela poeira caīcárea do ouvido humano (oloccnia), possuem os peixes verdadeiras pedras (otólitos).

Os rıns dos peixes denominam-se mesônefros e variam muito quanto à forma. Frequentemente apresentam-se unidos quer por uma das extremidades, quer pela outra, quer, mesmo, pela região medıana. Podem apresentar lobos de forma irregular que se dirigem para a frente ou para trás. Os canais condutores da urina (c. de Wolff), podem achar-se incluidos na massa formada pelos respectivos órgão ou localizados externamente na parte ventral dos mesmos. Dirigem-se para a região posterior 
e se unem em um duto comum de cuja parede pode destacarse uma vesícula urinária. Esta pode igualmente formar-se da parede da cloaca. O orifício urinário fica situado depois do ânus.

$O$ aparelho reprodutor feminino é constituido por um par de ovários. Apresentam-se êstes geralmente formados por lobos achatados presos às paredes da cavidade celomática por ligamentos peritoniais conhecidos por mesovários. Nessas condições, os ovos que se desprendem caem diretamente no celoma e vêm ter ao exterior através do orifício genital que fica atrás do ánus Este orifício pode projetar-se para o interior da cavidade do celoma na forma de um curto funil. Há, porém, casos, em que os ovários são incluidos em sacos especiais, que se cortinuam como ovidutos até os orifícios exteriores que ficam aos !ados do orifício anal.

Os ovos, postos aos milhares, ficam na água, onde são fertilizados, ai se desenvolvendo. Há, porém, peixes vivípảros, cLijos ovos são fertilizados internamente e se desenvolvem nos ovários ou nos ovidutos.

Os testiculos podem ser lobulados ou simples. Os espermátozóides, produzidos em câmaras dispostas radialmente, escapam-se através uma complicada rede de canais, para um duto deferente, que se encaminha para trás e se abre independentemente no exterior ou desemboca na região terminal do conduto urinário. 


\section{FISIOLOGIA DOS PEIXES E NOÇŌES DE SISTEMATICA}

A Fisiologia trata do funcionamento dos órgãos. Vejamos em primeiro lugar como funciona a pele do Peixe. Esta, além da protecão reforçada pela escamação, desempenha diversos outros papéis. Assim, possui glândulas uni ou pluricelulares, produtoras de um muco que se espalha por todo o corpo, tornandoc liso e dêsse modo diminuindo o atrito com a água e facilitando a natação. A pele do peixe pode se constituir em órgão de defesa, recobrindo-se de espinhos. Quando o peixe nada pacificanente os espinhos se apresentam obliquamente dirigidos para trás. Ao defender-se, movimenta os espinhos para a frente, eriçando-se todo. Glândulas veneníferas abrindo-se na pele e relacionadas com espinhos, são de comum ocorrência. Muitos peixes abissais têm a pele iluminada por órgãos luminescentes, cuja significação não está ainda perfeitamente determinada.

Vejamos agora a função digestiva. A bôca do peixe é guarnecida de dentes que servem muito mais para a preensão e deglutição dos alimentos, do que para a mastigação. Em virtude do seu modo de vida o peixe não precisa de glândulas salivares uropriamente ditas. Para nós essas glândulas são de grande utilidade, ajudando a mastigação e a deglutição. Não podemos mastigar com a bôca sêca e muito menos engulir. Mas o peixe, vivendo na água, não precisa de órgãos para molhar a bôca ou para umedecer os alimentos. Os peixes que se alimentam de outros, engolem-nos com facilidade, pois aquêle muco que os reveste facilita a deglutição. Do ponto de vista da digestão proprianıente, a saliva não faz muita falta, nem mesmo para os animajs que a possuem. O fermento que contém é específico para (s hidratos de carbono (polissacarídeos). Em virtude da curta permanência dos alimentos na bôca, a saliva não tem iempo de desdobrá-los, o que não prejudica a digestão, porque uns intestinos outros sucos desempenharão aquêle papel.

O estômago do peixe elabora um suco gástrico que possui pelo menos uma ênzima e o ácido clorídrico. A ênzima do estômago é da mesma natureza da que existe em outros animais e desernpenha o mesmo papel. E' conhecida por pepsina e é específica para o desdobramento das substâncias protêicas. Só atua em meio ácido, razão pela qual as glândulas gástricas sempre produzem o ácido clorídrico. O trabalho da pepsina não é completo. O desdobramento das proteinas não chega aos produtos finais, isto é, aos aminoácidos. Como o animal que serve de 
alimento é engulido inteiro, a pepsina geralmente atua no sentido de desintegrar os tecidos, libertando o conteúdo celular, no que é auxiliada pela intervenção direta do ácido clorídrico. Não seria mesmo necєssário que a pepsina desdobrasse completamente os alimentos protêicos, porque lá para trás, no intestino propriamente dito, há glândulas que elaboram líquidos de grande poder digestivo, que se incumbirão dessa tarefa. Assim, o suco pancreático possui uma ênzima denominada tripsina, que ataca os polipeptídeos resultantes da ação da pepsina, produzindo aminóácidos através de formas cada vez menos complexas. Tambémı ènzimas destinadas ao desdobramento dos hidrocarbonados e das matérias graxas, existem no suco pancreático. (Amílase, dissacárases, lípases). O fígado do peixe, como o humano, parece secretar uma bilis destituida de ênzimas. Não obstante, essa biliss desempenha notável papel na digestão. Sem ela, os outros fermentos não trabalham. Ela como que prepara o meio $\epsilon$ o material para o trabalho das ênzimas intestinais. Um dos principais papéis da bilis é o de pôr a matéria graxa em emulsão, sem o que essa matéria não poderá ser desdobrada. A parede intestinal elabora um suco que contém um complexo enzimático conhecido por erepsina, o qual se incumbe do desdobramento de produtos ainda bastante complicados provenientes da digestão das proteinas. (Polipeptídeos, dipeptídeos). Possui, além disso, uma substância denominada enteroquínase, que ativa uma fração da tripsina, o tripsinogênio.

De um modo geral, os alimentos, para o fisiologista, não têm a mesma significação que para o zootecnista. Aquêle não diria digestão do milho, da alfafa, da cana ou da carne. Considerando o alimento sob um ponto de vista mais exato, haveria de referir-se à digestão das substâncias que o constituem e então diria digestão das graxas, dos hidrocarbonados, das proteinas, etc

Pela atuação da pepsina, da tripsina, da erepsina e do ácido cloríảrico, as matérias protêicas, tenham elas a constituição que tiverem, desdobram-se até a produção dos aminoácidos. Com relação às substâncias hidrocarbonadas, o suco pancreático e o entérico se encarregam de transformá-las em monossacarídeos (glucose), que o organismo do peixe absorve com facilidade Relativamente às matérias graxas, as lípases pancreática e intestinais, auxiliadas pela bilis, desdobram-nas em glicerol e ácidos graxos, que são prontamente absorvidos.

Corn respeito ao funcionamento do pâncreas, já no peixe vamos encontrar uma sorte de hormônio, produzido no intestino e denominado secretina, que ativado pelo ácido clorídrico e 
absurvido pela mucosa intestinal, percorre o organismo todo para, chegando ao pâncreas, forçá-lo a derramar o seu precioso produto.

A absorção dos produtos da digestão é feita através da mucosa do tubo digestivo e especialmente pela mucosa intestinal. De posse dêsses produtos o peixe poderả reparar os gastos do organismo e fabricar a sua própria substância. Aliás, é essa a finalidade da digestão. O animal a efetua para obter unidades químicas para a formação das complexas substâncias que entram na composição do seu corpo. Em se alimentando, o cavalo fabrica substância de cavalo, o porco, substância de porco, o peixe, de peixe, e tudo com as mesmas sortes de unidades obtidas dos alimentos. O resultado do desdobramento é o mesmo para diferentes animais. A re-estruturação dos complexos químicos é que é diferente.

Examinemos agora um pouco da fisiologia da circulação.

Na circulação dos peixes há muitos fenômenos que não podem ser comparados aos que se observam no homem.

O coração pulsa automáticamente sob o império de influxos nervosos. A aurícula se contrai, fazendo o sangue passar para o ventrículo, que então se dilata. Os movimentos são diástoles e sístoles, como em nós. Há um sistema de válvulas que inıpedem o retrocesso do sangue. A elasticidade das artérias contribui para a movimentação da massa sanguínea. As artérias que chegam às brânquias nelas se capilarizam, permitindo a troca de gases entre o sangue e a água. O sangue se transforma então, de venoso que era, em arterial. E', pois, das brânquias quie parte o sangue nutridor, que se distribui por tôdas as partes do corpo. A causa principal da circulação nas veias é a vis a tergo ou a fôrça propulsora que vem de trás.

As artérias capilarizam-se mais uma vez nos tecidos para a trớa de substâncias entre êstes e o sangue e a linfa. Nos capilares os fênomenos de osmose são biològicamente controlados Embora em condições físicas favoráveis, muita cousa pode deixar de atravessar as paredes capilares. Incorporadas aos tecidos, as substâncias transportadas pelo sangue contribuem para a reparação dos gastos devidos aos fenômenos vitais e para a produção de tecidos novos. Os produtos de desassimilação que resultam das atividades nutritivas dos tecidos são levados pelo sangue para os órgãos encarregados de sua eliminação. Alguns dêsses produtos são previamente transformados no fígado.

Respiração. - O sangue vai para as brânquias venoso, oxigeñ-se e dêsse modo torna-se apto para alimentar as combustões que se processem de modo contínuo nos tecidos. O sangue que chega às brânquias já passou pelos intestinos onde se car- 
regou do material destinado à nutrição do organismo. Carregando-se agora de oxigênio o sangue se completa para o cabal desempenho de suas funções. $O$ transporte de oxigênio se efetua yor intermédio da hemoglobina, que é o principal constituinte dos glóbulos vermelhos do sangue. Essa substância oxida-se fàcilmente nos meios de alta tensão em oxigênio, cedend: êsse gás ao atravessar os meios de tensão mais baixa. Assim, chegando às brânquias depois de haver fornecido oxigênio aos tecidos, a hemoglobina se apodera do oxigênio que se encontra na água em uma tensão mais elevada, transformando-se num composto instável conhecido por oxi-hemoglobina. Este compasto, ao alcançar os tecidos nos quais o oxigênio, em consequêncja da permanente consumação, se encontra em estado de baixa tensão, dissocia-se com facilidade, cedendo aquêle gás. Essa dissociação é facilitada pela presença do gás carbônico resultante das combustões. O transporte do gás carbônico é bem complicado. Esse gás, em alta tensão nos tecidos, forma, com a água do plasma ou dos glóbulos, o ácido carbônico. A hemoglobina, desfalcada de oxigênio, comporta-se como um ácido fraco, cedendo as suas bases ao ácido carbônico, que com elas forma bicarbonatos. Nas brânquias a hemoglobina se oxida, passandc a funcionar como um ácido mais forte e dêsse modo recuperando as bases que havia perdido. $O$ ácido carbônico então dissocia-se, passando o gás carbônico para a água ambiente. Os glóbulos vermelhos possuem uma ênzima, a anídrase carbônica, que facilita a formação do ácido carbônico e a sua dissociação.

Uma parte bem menor do gás carbônico é transportada em combinação com os grupos "amino" da hemoglobina e de outras protemas.

A função excretora é desempenhada pelos rins (mesônefros), com a colaboração do fígado, que se encarrega da preparaçãi de certas substâncias a serem eliminadas.

Alguns detalhes da estrutura dos rins ainda primitivos dos peixes se fazem agora necessários para a compreensão do funcionamento dêsses órgãos. Assim, a unidade anatômica dos rins, relacionada com a função urinária, é o nefron, que, salvo algumas excepções, consta de um glomérulo, ou seja, um novêlo capilar, e uma cápsula que contém o glomérulo. A cápsula para onde entra a arteriola glomerular se continua por um tubo que dá vasão ao produto filtrado no glomérulo. Esse tubo, nas proximidades da cápsula, dá origem a um ramo que se abre no celoma por um funil vibrátil denominado nefrôstoma e se continua por uma porção proximal mais ou menos contorcida e de função glandular. Os produtos de excreção lançados à cavidade celo- 
mática são recolhidos pelos nefrôstomas e conduzidos para o extericr através dos tubos uriníferos. $O$ papel dos glomérulos é o de eliminar a água que tende a aumentar no sangue. Em virtude da pressão sanguínea que se eleva nos glomérulos, processa-se uma filtração do sangue, que deixa passar a água uiru dos constituintes da urina. Algumas substâncias úteis (glucose, sais), que por ventura atravessem o filtro glomerular, são recuperadas na parede dos tubos uriníferos, que se encarrega de fazê-jas voltar para o sangue. Os principais produtos de excrecão provenientes do metabolismo das matérias protêicas (uréia, ácido úrico), podem ser recolhidos do celoma pelos nefrôstomas ou ser incorporados à urina pela atividade secretora das células que formam a parte proximal da parede dos tubos uriníferos.

Reprodução. - As células reprodutoras denominam-se gâmetas. As produzidas pelo macho chamam-se espermatozóides e as produzidas pela fêmea, óvulos. A união de óvulo e espermatozóide, indispensável para o desenvolvimento do organismo, denomina-se fertilização ou fecundação. Os óvulos virgens vêm ter à água e sôbre êles são lançados os espermatozóides. Uma espécie de fertilizina que se desprende dos óvulos concorre para atrair quimiotaticamente os espermatozóides, orientandoi-os. Embora mais de um espermatozóide penetre no óvulo, um só o fecunda. A fecundação propriamente dita é a fusão d.) núcleo do óvulo com o núcleo do espermatozóide. Os núcleos dos gàmetas que se juntam veiculam diminutos elementos conhecidos por cromossômios, os quais têm a desempenhar importante papel na hereditariedade. Tôdas as cousas que o peixe herda de seus pais, chega-lhe por intermédio dos respectivos gâmetas. Cada espécie de peixe possui nas células que formam o seu corpo um número característico de cromossômios. Por ocasião da reprodução, os gâmetas que se formam nas gônadas de cada pai reduzem, por um processo assás complicado, o número de cromossômios, para a metade. Assim por exemplo, se os peixes de uma dada espécie possuissem 30 cromossômios em suas células, haveriam de produzir gâmetas com apenas 15. Nessa amostra reduzida existe um elemento de cada uma das quailidades encontradas nas células do corpo, pois, como sabemos, estas possuem dois elementos de cada uma das sortes. $O$ processc segundo o qual os cromossômios em duplicata se repartem pelos gâmetas de sorte que todos êles fiquem com um representante de cada qualidade, denomina-se meiose. A fertilização restabelece o número típico da espécie. $O$ ôvo, no caso, teria 30 cromossômios, dois de cada sorte, tal como se encontravam nas diferentes células do corpo dos indivíduos que 
contribuiram para a sua formação. Quando o ôvo se segmenta para produzir o embrião, os cromossômios se dividem longitudinalmente ao meio e cada célula que se origina recebe os mesmos 30 elementos característicos da espécie. E assim, até que se complete a formação do peixinho. Quando êste se tornar adulto e se reproduzir, o mesmo processo reducional se repetirá e, à semelhança do que se passou com os seus pais, também êle darà origem a gâmetas com metade do número de cromossômios $\mathbf{E}$ dêsse modo será conservado o número característico da espécie.

O espermatozóide contribui com os centrossômios para a formação dos pólos que no ôvo orientam os cromossômios resultanies da divisão para as células que se vão formar. Caso mais de um espermatozóide fertilizasse o mesmo óvulo, três ou mais pólos poderiam formar-se e então os cromossômios seriam desigualmente repartidos pelas células resultantes da segmenteçãa e o desenvolvimento do embrião seria porisso grandemente prejudicado. Eis a razão pela qual um só espermatozóide toma parte na fecundação, um só núcleo masculino se fundindo com o unico núcleo do óvulo.

Sendo o ôvo do peixe muito rico em vitelo, a segmentação se processa em um dos pólos e o embrião inicia o seu desenvolvimento na forma de um pequenino disco. Mais tarde todo o vitelo é envolvido pelo saco vitelino que aos poucos se vai formando $\epsilon$ que acaba se constituindo numa espécie de divertículo do tubo digestivo do embrião, que dêle retira os princípios nutritivos de que tanto carece para se desenvolver. Em geral, quando o peixinho nasce, o saco vitelino, ainda não esgotado, pode ser visto em sua região ventral.

Sistemática. - E' a parte da Zoologia que cuida de grupar os animais de acôrdo com as suas afinidades. Baseando-se em caracteres muito evidentes o naturalista organiza grandes grupos. dentro dos quais vai estabelecendo grupos cada vez menores, até chegar à unidade da sistemática, que vem a ser a espécie Os grupos, pela ordem decrescente da sua extensão, denominam-se ramos, classes, ordens, famílias, gêneros e espécies, podendo-se, se for necessário, organizar divisões intermediárias, como por exemplo, sub-ramo, super-classe, sub-classe, superorciem, sub-ordem, super-família, sub-família, sub-gênero e suespécie. Quanto mais elevado for o grupo, tanto mais extenso e mais bem definido. Os grupos inferiores são os menores e cada vez se separam com mais dificuldade.

A sistemática dos Peixes é das mais complicadas e varia de um especialista para outro. Muitos procuram reunir grupos previamente reconhecidos como válidos, ao passo que outros 
procuram desmembrá-los. Não só o elevado número de espécies presentemente conhecidas, mas também o complicado nome conferido às inúmeras subdivisões, torna muito árdua a tarefa de dar algumas noções, por mais sucintas que sejam, acêrca da sistemática dos Peixes. Enfim, apenas para não passar em branco sôbre o assunto, vou dizer algumas palavras.

Todos os animais pluricelulares (Metazoários) providos de uma corda dorsal, constituem o Ramo Chordata. O peixe está nessas condições, sendo, porisso, incluido nesse Ramo. O Ramo Chordata é constituido por alguns Sub-ramos, dentre os quais um formado pelos cordados providos de um endosquêleto de natureza óssea ou cartilagínea geralmente armado numa coluna constituida por segmentos articulados denominados vértebras. Ėste é o Sub-ramo Vertebrata, no qual se incluem os Peixes

O Sub-ramo Vertebrata compreende um certo número de superclasse e de classes, como segue :

Superclasse Agnata. - Compreende peixes primitivos destituidos de maxilas e com nadadeiras pouco desenvolvidas ou ausentes.

Podemos reccnhecer aqui pelo menos uma classe atual :

Classe Cyclostomata. - Animais de pele nua, escorregadia, de bôca arredondada que funciona como ventosa, sem nadadeiras pares, com 6 a 14 fendas branquiais alinhadas de cada lado.

Esta classe compreende duas ordens :

Ordem Myxinoidea

Ordem Petromyzontia

Superclasse Gnathostomata. - Peixes providos de maxilas.

Classe Chondrichthyes. - Encerra peixes providos de nadadeiras pares, de endosquêleto cartilagíneo pelo menos em grande parte e recobertos de pequenas escamas homólogas aos dentes.

Ordem Elasmobranchii. - Esqueleto inteiramente cartilagíneo, corpo recoberto por pequenos dentículos embutidos na pele, com um espiráculo e fendas branquiais expostas, intestino com válvula espiral e coração com um cone arterioso. Tubarões.

Ordem Holocephali. - Pele geralmente nua, espiráculo auserte e fendas branquiais ocultas, vértebras pouco desenvolvidas e placas ósseas em lugar dos dentes.

Classe Osteichthyes. - Endosquêleto pelo menos em grande parte ósseo, corpo recoberto por escamas ou placas romboi- 
dais, brânquias protegidas por um opérculo ósseo, com vesícula natatória, bôca com maxilas, nadadeiras pares.

Subclasse Choanichthyes. - Nadadeiras pares com um lobo basal, orifício nasal abrindo-se no teto da cavidade oral, vesículas natatórias bem desenvolvidas funcionando como pulmão, corpo recoberto por escamas arredondadas ou romboidais.

Superordem Crossopterygii. - Nadadeiras pares com um lobo basal arredondado, com um espiráculo, com duas nadadeiras dorsais.

Superordem Dipnoi. - Nadadeiras pares com um eixo alongado provido de ramos laterais, espiráculo ausente, com piacas dentais, com válvula espiral e cone arterioso. Aqui se encontram os peixes pulmonados do Amazonas.

Subclasse Actinopterygii. - Nadadeiras pares sem eixo e sem

lobo basal, com uma nadadeira dorsal, saco nasal sem abertura interna.

Ordem Chondrostei. - Endosquêleto em grande parte cartilagíneo, com válvula espiral e cone arterioso, espiráculo geralmente presente, escamas ganóides.

Subordem Polypterini. - Nadadeiras peitorais com um lo. bo basal, vértebras providas de centro, com um par de pulmões situados ventralmente e se abrindo na parede ventral do esôfago.

Subordem Acipenseroidea. - Nadadeiras pares sem lobos, peixes providos de um longo focinho ou rostro, escamas mais ou menos degeneradas, pulmões abrindo-se dorsalmente, centros vertebrais não desenvolvidos.

Ordem Holostei. - Esqueleto moderadamente ossificado, centros vertebrais geralmente bem desenvolvidos, escamas ganóides ou ciclóides, espiráculo ausente, vesícula natatória simples, situada dorsalmente e se comunicando com a parede dorsal do esôfago, cone arterioso presente e válvula espiral vestigial.

Ordem Teleostei. - Esqueleto quase completamente ossificado, centros vertebrais completamente desenvolvidos, escamas do tipo ciclóide ou ctenóide, espiráculo ausente, vesícula natatória simples, dorsal, frequentemente sem comunicação com o esôfago, válvula espiral ausente, cone arterioso vestigial. Aqui se encontram os peixes mais comuns, geralmente conhecidos por peixes ósseos, e que mais interessam à Piscicultura. 


\section{CURIOSIDADES DA VIDA DOS PEXXES}

Peixe grande come peixe pequeno. Isso não exprime simplesmente uma norma alimentar de peixes. Peixe grande come peixe pequeno traduz uma grande lei biológica. Nessa expressão se acha a lei da luta pela existência. Do ponto de vista fisiológico, até o homem já comeu o próprio homem. Ainda hoje, sob o ponto de vista sociológico e em homenagem aos peixes, diremos: homem grande come homem pequeno. Esses homens grandes, comedores de homens pequenos, são os terríveis "tubarões".

A luta pela existência, em tôdas as suas modalidades, não passa de uma luta pela comida. A função de comer é a mais alta e nobre de tôdas as funções. Nós preferimos dizer que a função nobre é a função do coração. Dizemos que amamos com o coração só porque êsse órgão, extremamente sensível, indica as nossas emoções pulsando mais aceleradamente.

O intestino, entretanto, é o mais nobre, sob todos os pontos de vista. Começa por ser o mais antigo de todos os órgãos. Primeiro formou-se o intestino e depois tudo o mais. Durante uma grande etapa da vida dos animais, não havia outro orgão. Era só a cavidade digestiva. No embrião dos Metazoários, uma das primeiras cousas que aparecem é o tubo digestivo. Em virtude da sua antiguidade aperfeiçoou-se tanto, que chegou a se tornar quase insensível às emoções que costumam alterar o ritmo do coraçãn. Os intestinos são tão considerados na milenária cultura orjental, que os chinêses costumam empregar esta expressão: "amigo dos meus intestinos", para com ela manifestarem uma profunda afeição.

O mar está repleto de organismos. Há peixes que os habitam em tôdas as profundidades e latitudes. São muito mais numerosos que os vertebrados terrestres somados. Isso por vários motivos e principalmente por ser a Terra um planeta quase que inteiramente líquido: é uma bola de água girando no espaço.

A luta contida na expressão "peixe grande come peixe pequeno" promoveu a mais variada diversificação das formas. Peixes aperfeiçoaram-se na caça, enquanto outros aprenderam a fugir.

O que devemos entender por peixe grande e peixe pequeno?

O naturalista considera grande o peixe que tenha por ex€mplo $15 \mathrm{~m}$ de comprimento. Um peixe nessas condições, como o tubarão-baleia (Rhincodon), de fato nos impressiona 
pelo tamanho. Precisamos contar umas dezenas de passos até percorrê-lo de uma extremidade a outra. E' uma verdadeira montanha de carnes !

E peixe pequeno, o que vem a ser?

Um peixe pequeno, que mereça essa denominação, deve ser alguma cousa extremamente diminuta. $O$ menor peixe conhecido era tão delicado em relação aos outros, que o autor que o descobriu tornou-se célebre por isso. (Média $28 \mathrm{~mm}$ ). Era realmente uma maravilha! O seu descobridor ficou tão impressionado, achou-o tão formoso, que lhe deu o nome de Heterandria formosa. A descoberta de uma formosura como essa despertnu grande interêsse e muitos cientistas começaram a procurar peixes pequenos.

Um belo dia, alguém pegou um peixe de apenas $18 \mathrm{~mm}$ de comprimento. Foi logo batizando-o por Heterandria minor. A glória dessa descoberta foi efêmera, pois logo outro pesquisador descobre um peixe medindo nada mais que $10 \mathrm{~mm}(1 \mathrm{~cm} !)$. Provinha dos mares Filipinos. Entusisasmado, o seu descobridor o proclama "o menor dos vertebrados!".

$O$ encontro dêste peixe, que tem um nome bastante complicado, Mistichthys luzonensis, pôs um pouco de água na fervura do entusiásmo dos cientistas. Parecia impossível que peixe ainda menor pudesse existir. Entretanto, um pesquisador que raciocinasse com justeza, diria: Tamanho não tem limite. E se poria a buscar.

Foi, de fato, o que fez alguém. $\mathrm{E}$ tanto procurou, que achou uma das mais empolgantes maravilhas da natureza : um peixe de $5 \mathrm{~mm}$ de comprimento! A maravilha consiste em a natureza haver colocado dentro de tão ínfima criatura, tôda uma completa organização. Ali existe um tubo digestivo secretando ênzimas que tão bem desdobram os alimentos como as do tubarão de muitos metros de comprimento. Lá está um coração batendo $\mathrm{em}$ ritmo certo e fazendo o sangue circular por artérias e veias. Lá se acha igualmente um cérebro que pensa à maneira de peixe e que elabora influxos que percorrem os mais finos nervos oue podemos imaginar. Este peixinho possui um fígado do tamanho da ponta de um alfinete, que funciona tão bem como o enorme fígado de um grande peixe. O fígado de 9 ou 10 quilos do gigante, não leva vantagem alguma sôbre aquêle minúsculo ponto do pigmeu. Essa maravilha não é outra senão a célebre Fandaka pygmea das costas Filipinas.

Nessa luta incessante de peixe contra peixe, os que perseguem especializaram-se na velocidade, chegando os campeões a percorrer uma milha por minuto, ou seja, mais de $100 \mathrm{~km}$ por hora, nãc havendo navio que possa alcançá-los. Nadam agitando 
a cauda com movimentos vigorosos e se equilibrando com as nadadeiras laterais. Os que fogem, para não serem comidos, especializam-se de outras maneiras. Assim, uns aprenderam a andar As suas nadadeiras, modificadas, assemelham-se a dedos. Andan: no fundo das águas, entre a vegetação e as pedras, em lugures que os nadadores velozes não podem atingir. A adaptação especial dêstes peixes anula a velocidade dos grandes comedores.

Que um peixe ande, para se defender, no fundo do mar, é cousa bastante razoável. Trata-se, afinal, de uma adaptação do organismo ao meio, afim de poder triunfar na luta pela existência. Seria porisso natural, que os peixes que aprenderam a andar, nâo quisessem sair das águas. No entanto, sairam e se puzeram a caminhar pela terra. Estes peixes atravessam a estrada, passam por baixo da cêrca, entram no pasto e procuram, lá ao longe, novas águas para nelas mergulharem. São mesmo de causar espanto! Com franquesa, se eu fôsse andando por uma estrada e encontrasse um grupo de peixes cortando o meu caminho... eu ficaria por certo espantado!

Pois bem, isso acontece. $\mathrm{E}$ acontecem cousas ainda mais espantosas: peixes que sobem às árvores. Imaginem os senhores que a gente encontrasse um indivíduo preparando-se para atirar para o tronco de uma árvore e que êle nos dissesse : psiu ! não faça barulho que vou matar um peixe... Acho que a gente até seria capaz de ir ao Hospício, trazer um enfermeiro e, apontando para o estranho caçador, dizer simplesmente : é aquêle!

$\mathrm{Na}$ luta pela existência os peixes aprenderam a saltar, embora nenhuma estrutura especial se formasse para isso. Os peixes não são como os gafanhotos, aos quais a natureza conferiu órgãos que funcionam como molas propulsoras. Não, os peixes saltaru como nós, fazendo grandes esforços.

Que os peixes saltassem para vencer corredeiras e cachoeiras, na ânsia de escapar aos seus perseguidores, seria perfeitamente compreensível. Mas que saltem por esporte, já parece exagero. No entretanto, existe um peixe (o peixe-agulha), que pratica o esporte do salto. Salta um pau ou um pedaço de papel, de um lado para outro. E enquanto o objeto vai rodando, o peixe vai saltando para lá e para cá. Salta uma tartaruga e torna a saltá-ia. Que pretenderá o peixe ? Parece que nada. No entanto vai saltando. Só mesmo por esporte...

Também peixes existem que voam quase meio quilómetro à cêrca de $10 \mathrm{~m}$ de altura. Mas não voam como as aves. Planam com as nadadeiras peitorais e às vezes também com as abdominais, constituindo-se em verdadeiros planadores. Navegam primejro com grande velocidade riscando a superfície das águas e 
num esfôrço supremo, dando tudo o que têm, lançam-se ao ar, distendem as nadadeiras e lá se vão voando, por dezenas e dezenas de metros para então baixar ao seu elemento.

Sãc adaptações como essas, que resultam da luta pela existência contida na expressão "peixe grande come peixe pequeno".

Năo é só relativamente à locomoção que a adaptação se faz sentir Com respeito à nutrição vamos encontrar peixes que se alimentam por processos muito particulares, interessantes e até mesmo estravagantes.

Po: exemplo, há um peixe que aprendeu a caçar insetos, dando tiros. Parece que a primeira vez que viu um inseto, pensou : "Se eu tivesse aqui uma pedrinha... seria capaz de derrubá-lo " Possui êsse peixe a bôca conformada de tal modo, que Ihe permite cuspir ao longe. $\mathrm{Na}$ falta de pedrinhas, aprendeu a derrubar os insetos, cuspindo... Alguns se fizeram especialistas tão notáveis, que não erram os tiros. Os observadores verificaram que os filhotes, desde pequenos, vivem cuspindo. Os grandes campeões atiram ao vôo e não perdem bala. Dão vário tiros seguidos e rápidos, como se fôsse como metralhadora.

Há muitas outras adaptações curiosas relativas à nutrição dos peixes.

Mas não foi só aí que a natureza agiu modificando os peixes, para que os peixes pequenos escapassem à sanha devoradora dos peixes grandes.

Peixes há, que aprenderam a viver em simbiose com outros organismos. Existe um pequeno peixe que explora as Anêmonas, seres que mais se parecem com plantas. Têm elas um corpo cilíndrico provido de tentáculos dispostos como as pétalas de uma corola e que se movem muito lentamente. Tipos como êsses se reunem em colônias e, à semelhança das Hydras, sãu arinados de órgãos urticantes. No meio das Anêmonas, êste interessante peixe vai morar. As Anêmonas encolhem os tentáculos para não ferir o peixe com o qual se acostumaram a viver.

Quando o peixe quer alimentar-se, navega com medo e muito às pressas pelas imediações, apanha vários bocados de material nutritivo e leva-os para a sua residência, para depois comer sussegado. O alimento recolhido é bastante para si e para a colônia que o hospeda. As Anêmonas combatem os inimigos do peixe e o defendem em troca da provisão que êste costuma trazer-lhes.

Conhece-se um Celenterado (Physalia) que consiste numa espécie de bóia que flutua à superfície das águas. Debaixo dela se ocultam diversos indivíduos variadamente modificados para o desempenho de diferentes funções. (Hidrantes especializa- 
dos). A maioria são os macozóides, ou seja, indivíduos armados para a luta. Aquela espécie de flutuador é uma verdadeira armadilhá para os peixes de que o Celenterado se nutre. Buscando nela refugiar-se, os perseguidos encontram a morte na trama dos tentáculos que lhe ficam por baixo.

Há um só peixe, o Nomeus, que pode abrigar-se sem perigo entre os tentáculos de Physalia. Serve êle como isca para atrair outros peixes. Arriscando-se pelas vizinhanças é logo perseguido e foge para baixo do flutuador, escondendo-se no meio dos tentáculos. Assim, arrasta para a morte os seus perseguidores. Ele, entretanto, ali vive, entre as armas mortíferas do Celenterado, que lhe são inofensivas e até o protegem em troca das prêsas incautas que êle conduz.

Com respeito à reprodução também se conhecem curiosas adaptaçōes.

Muita cousa interessante existe relativamente aos cuidados que os pais dedicam aos ovos e à prole.

Há um fato, que bem poderia servir de exemplo a muitos pais de família. E' o caso dos peixes que recebem na bôca os ovos fertilizados e aí os conservam até o momento da eclosão, nela abrigando os filhotes por um tempo maior ou menor, até que possam ser lançados à água. Passam, nêsse solícito mister, tôda a sorte de privações, emagrecem, perdem as feições... mas aguentam firmes.

Un dos exemplos mais interessantes é o dos peixes Hippocampus, cujos machos possuem uma bolsa incubadora. $\mathrm{O}$ útero é da fêmea, mas os filhos nascem da barriga do macho. Se a natureza experimentasse conosco êsse esquisito processo, estou certo, a humanidade não existiria, porque não creio que o homem concordasse em dar à luz mais de uma vez...

Um dos fenômenos mais empolgantes da vida dos peixes, é o fenómeno das migrações. Neste particular existe a interessante história conhecida por "epopéia das enguias".

Sábia-se que aquêles peixes viviam em águas doces e que se reproduziam no mar. Muita gente vira as enguias saindo dos rios e se dirigindo para o oceano. Nunca, porém, foram vistas, voltando às águas doces. Enguias pequeninas eram porém algumas vezes encontradas na embocadura dos rios. Pensava-se que elas aí tivessem nascido. A verdadeira história, entretanto, era bem outra.

Dada a importância econômica das enguias, uma comissão se constituiu para estudar o complicado assunto, tendo confiado a drreção dos trabalhos ao dinamarquês Johann Schmidt, que de ticou tôda a sua existência ao esclarecimento de tão magna questão. 
Todos os comandantes de navios foram incumbidos de coletar material para as pesquisas. Em todos os mares, em qualquer latitude e a diversas profundidades, foram recolhidas amostras destinadas aos laboratórios de pesquisas. Reunidos e analisados os dados, pôde Johann Schmidt, após 30 anos de intensos trabalhos, contar a história que agora se pode repetir em pouquíssimas palavras.

Havia, desde os tempos de Aristóteles, um animal marinho chamado Leptocephalus e que era bem conhecido dos antigos. Porém, ninguém jamais suspeitara da existência de qualquer relação entre os Leptocephali e as enguias. Entretanto, hoje sabemos, que quando chega a ocasião das enguias se reproduzirem, elas navegam os mares, milhas e milhas, para lá, muito ao longe, largarem os seus ovos. Navegam fundo, pois ninguém jamais pegou qualquer enguia em alto mar. Os recém-nascidos dos ovos das enguias são os Leptocephali, que até então foram considerados como uma espécie diferente, nada tendo que ver com as enguias.

Pouco depois de nascidas, as enguias começam a sua longa peregrinação através dos mares. $\mathrm{E}$ aqui é que está um dos pontos mais curiosos de tôda a história : Nascem nos mares enguias americanas e européias e vão, cada espécie para o seu destino, nunca se encontrando um só exemplar da enguia americana nos rios da Europa, ou vice-versa. As americanas vêm para os rios da América e as européias se dirigem para os rios europêus.

Levam cêrca de 3 anos nadando pelos mares imensos. Quando entram no quarto ano apresentam o aspecto característico das enguias jovens encontradas na embocadura dos rios ou mesmo subindo-os. Nas águas doces vivem 10, 15 e até 20 anos. Atingindo a maturidade, demandam os mares em busca da região em que costumam reproduzir-se.

Fissa história nos mostra o que se pode conseguir com trabalhc científico inteligente e perseverante.

Nesta luta - porque tudo gira em tôrno da luta pela existência - vamos travar conhecimento com um dos fatos mais extraordinários que se conhecem. E' o de um peixe relativamente pequeno, que resolveu por os seus ovos na terra. Perfura a praia para efetuar a postura. Os ovos se desenvolvem em 15 dias. Porém, não eclodem se não forem agitados pelas ondas. Estas devem intervir exatamente no momento de nascer, isto é, 15 dias após a postura. Os hábitos dêsse peixe são tão exatos, que quando os boletins meteorológicos anunciam a hora das mais altas márés, os turistas se dirigem às praias, onde en- 
contrarão o peixinho, aos bandos, na faina da desova. $O$ peixe vem na crista de uma onda e quando esta se arrebenta na areia, desembarca célere, põe os ovos e volta na mesma onda ou na seguinte. A onda escolhida é sempre uma das que avaçam mais, sem que contudo seja a mais longa.

A maré alta é mais alta nas luas cheias e novas. $O$ peixe vem exatamente numa dessas luas.

Na proxima maré alta, decorridos 15 dias, as ondas de maior alcance atingem os ovos e os agitam, dando-se então a eclcisão. O peixe nunca vem na onda mais longa, porque então, na maré mais alta da proxima lua, talvez os ovos não pudessem ser suficientemente agitados.

Devido ainda à adaptação, encontramos peixes com olhos bifocais. Apresentam êsses olhos uma linha divisória transversal bem ao meio. A parte de cima fica fora da água e se destina à visão do que se passa no ar. A parte de baixo é para a visão na água.

Temos nos fatos aqui narrados os fundamentos para aquilo que poderemos chamar "a vida psíquica dos peixes", assunto da próxima palestra. Naturalmente, não pretendemos que a vida psíquica dos peixes seja como a vida psíquica do homem. A nossa pretenção não vai além de querermos encontrar nos peixes os primeiros lampejos daquilo que veio constituir mais tarde a alma humana. Não poderemos descobrir nêles as mais altas funções cerebrais que conhecemos no homem, porque isso não seria possível em seres dotados de um cérebro tão primitivo. Os peixes não possuem estruturas que sirvam de substrato às mais elevadas funções psíquicas. $\mathrm{E}$ isso porque falta-lhes o córtex cerebral cinzento, sem o qual não há vida propriamente psíquica.

Qual o motivo que nos leva a buscar nos peixes as bases da psicologia humana ? A razão está em que consideramos os peixes como um dos mais remotos ancestrais do homem.

Proviemos de peixes, já não resta qualquer dúvida. A evolução é um fato. Não é possível querer negá-la diante das provas que hoje possuimos.

Vimos em alguns fatos aqui referidos, indicações de que os peixes um dia sairiam definitivamente da água. Para isso precisariam aprender a viver na terra. Teriam, em primeiro lugar, 
que aprender a respirar de modo definitivo, o ar atmosférico Pois isso se deu. O peixe modificou-se e se transformou em anfibio, isto é, num animal terrestre que ainda precisa da água para nela desovar. A maior parte dos Anfíbios voltam periodicamente à água por ocasião da desova, pois os girinos, que muito se assemelham aos peixes, ainda respiram por brânquias. Estes, aos poucos se metamorfoseiam, adquirem pulmões e vêm para a terra. Alguns Anfíbios atuais conseguiram desligar-se por completo do primitivo habitat aquático. Os Répteis, que vieranı depois, consolidaram-se na terra em consequência, principalmente, de modificações adaptativas sofridas pelos ovos.

A evolução, conforme dissemos, é um fato. No domínio científico, ninguém mais duvida que ela se tenha processado. $O$ que ainãa se discute são as teorias que visam explicar o mecanismo àos processos evolutivos operantes na natureza. Os leigos, incapazes de apreciar o valor das provas que a ciência lhes apresenta, não têm senão confiar. Quando o professor afirma aos seus alunos que a água resulta de uma combinação de dois volumes de hidrogênio e um de oxigênio, êles aceitam em confiança. mesmo sem ter compreendido o mecanismo do processo químico de que a água se origina. Porque, então, querer duvidar da evolução ? Por motivos religiosos ? Pois, se for esta a causa, podem ficar sabendo que a evolução em nada, absolutamente, contraria a religião.

Aceitar que o homem proveio do macaco não diminui a crença $\in m$ Deus. Até pelo contrário. Se a transformação que tirou o homem da animalidade e o conduziu ao lugar que hoje ocupa na sociedade foi dirigida por Deus, curvemo-nos reverentes a grandiosidade da sua obra. 


\section{A VIDA PSIOUICA DOS PEIXES}

Tratando dos pontos de contacto entre a Religião e a Ciência, tive a finalidade de combater a opinião errônea, segundo a qual a Ciência entra em conflito com a Religião.

Absolutamente, a Ciência não contraria a Religião. E' muito fácil oferecer um raciocínio para comprovar esta afirmativa. Os que em Deus creem, dizem ser êle a Suprema Verdade. Pois bem, a Ciência buscando a verdade, aproxima-se evidentemente de Deus.

A Bíblia pode ser encarada sob dois aspectos : o religioso e o profano. O religioso só pode ser interpretado sob as luzes de guias versados na matéria, sem qualquer espírito de crítica. Pelo lado não religioso, leigo ou profano, pode-se estudar a Bíblia como qualquer outra obra, fazendo-se anotações à margem, coilcordando-se ou discordando-se das afirmações nela contidas. E' sob êste último aspecto que o cientista analisa a Bíblia.

A Ciência, muitas vezes, coloca nas mãos dos religiosos argumentos para uma melhor compreensão do significado simbólico das passagens bíblicas. Vejamos, por exemplo, o dogma da Virgindade de Maria. Quando se descobriu a partenogênese, isto é, a faculdade do ôvo dar um ser perfeito sem necessitar do concurso do macho, o bispo de Paris, ao felicitar o descobrinor de tão importante quão significativo fenômeno, declarara ver naquele fato natural, a chave que permitiria esclarecer o mistériu dá virgindade. Foi-lhe respondido que o fenômeno, pecuLiar aos organismos mais simples, com tôda a certeza não poderia estender-se ao homem.

Entretanto, hoje, partindo de ovos virgens da rã, podemos chegar ao estado adulto. $\mathbf{E}$ a rã, como sabemos, não se reproduz naturalmente por partenogênese. Estamos agora na fase experimental da partenogênese em Mamíferos. E nesse terreno já se conseguiu muito. Cada vez mais nos aproximamos do momento $\mathrm{em}$ que poderemos criar um ser humano a partir de um ôvo não fecundado. A Ciência, por conseguinte, está oferecendo à Religião, as bases para aceitar uma partenogênese humiana, pelo menos em casos excepcionais.

Há uma lacônica passagem da Bíblia, que resa assim: "E havia naqueles tempos gigantes sôbre terra". Isso fez com que os religiosos do passado andassem à procura de ossos de grandes dimensões, para expô-los nas igrejas. Estavam, pois, os religiosos, esforçando-se para comprovar uma asserção bíblica. Ficou, porém, demonstrado, que, aquêles ossos gigantescos per- 
tenciam a Répteis (Dinossáurios) que floreceram em épocas mui remotas.

Achavam-se as cousas nêste pé, quando um paleontologista holandês, Koenigswald, encontrou, numa farmácia da China, um dente de estrutura humana, porém muito maior que os dentes do homem contemporâneo. Querendo acreditar que se enganara, cada vez mais se convencia de que estava certo. $O$ dente era mesmo um dente humano. Foi esta a pista que o levou a novas e importantes descobertas. $\mathrm{E}$ assim, a Ciência pôde oferecer à Religião dados muito concludentes acêrca dos gigantes referidos naquela singela passagem do Genesis.

A Religião, pois, deve ficar satisfeita com a Ciência, pois que esta vem buscando as provas de verdades bíblicas, que ela não logrou encontrar.

Deus fez Eva de uma costela de Adão. Eis aí uma das mais belas revelações da Bíblia. Tomada assim ao pé da letra, é um ábsurdo. Queremos ser religiosos, mas queremos também compreender.

Quando Deus fez o homem, já havia feito os outros animais. Machu e fêmea os criara, para que se reproduzissem segundo a sua espécie. E nunca precisou Deus tirar uma costela ao macho, para com ela fazer a fêmea. Usou de processos, que mais tarde iria aplicar ao homem. E' verdade que Deus ocultou no "Fiat" famoso, os métodos por Êle usados na sua obra criadora. Mas ao homem deu inteligência, para que um dia pudesse entrar na posse da verdade. $\mathrm{E}$ o caminho que leva o homem a descobrir tôdas as verdades, é a Ciência.

Havendo Deus feito o homem do barro, quis revelar que a matéria bruta precedeu à viva, na longa história da evolução dos seres organizados, aliás como nos provam as ciências. Ao fazer a mulher, deveria ter procedido como antes, ao criar a fêmea das outras espécies. A Bíblia fala em costela, como poderia ter falado em dente ou em qualquer outra parte do corpo do homem. $O$ intúito foi o de estabelecer uma moral para a humanidade, mostrando que homem e mulher se completam como duas partes de um mesmo todo. Se alguma cousa Ele tirou a Adão, não foi evidentemente uma costela e sim um cromossômio, tal como havia feito com os outros animais e de conformidade com o que nos ensinam as ciências biológicas nos seus mais belos capítulos.

Pará completar o assunto da palestra anterior, desejo me referir a mais algumas curiosas adaptações dos peixes à luta pela existência. Digamos, pois, algumas palavras sôbre os órgãos elétricos. São de estrutura anatômica complicada e produzem eletricidade por meios químicos. $\mathrm{O}$ que há de mais interessante a assinalar, é o potencial da carga que podem produzir. Esse 
potencial é cousa que só recentemente aprendemos a medir. E' que a descarga elétrica era tão rápida, que os aparelhos de física não podiam registrá-la. Foi preciso que os biologistas se aliassem aos físicos para resolver a quesião e aparelhos especiais fôssem construidos. Afinal conseguiu-se verificar que a descarga dos peixes elétricos é de cêrca de 600 volts e 1000 watts, Năo podemos ainda aproveitá-la na iluminação, por ser extremamente rápida.

Outra curiosidade é a resistência de certos peixes ao congelamento.

Um cientista americano recebeu uma consulta de um indivíduc que lhe perguntava se os peixes podiam congelar-se. Respondeu, que os peixes não, mas a água em que os peixes se encontram, sim. Na água congelada pode o peixe viver muitos dias.

Peixes que respiram por meio de pulmões e que passam grande parte do ano no interior de buracos feitos na terra úmida, são outra curiosidade dêsses interessantes animais.

$\mathrm{O}$ que parece muito estranho, é que certos peixes tenham aprendido a pescar.

Há de fato um peixe, que se denomina Lophius piscatorinus devido à sua singular atividade, que pratica o esporte da pesca!

Êsse peixe leva consigo uma "varinha", que é uma modificação de um dos raios da nadadeira dorsal. Cousa curiosa é que èsses peixes pescadores têm o mesmo temperamento dos pescadores humanos. Os homens nervosos não são bons pescadores $\mathrm{O}$ bom pescador precisa ser calmo, andar de vagar e sozinho Tem que pôr a linha na água e esperar pelo peixe. $O$ peixe pescador possui todos os requisitos exigidos para a prática dd pescaria. Nada vagarosamente, escolhe um cantinho solitário e espera pachorrentamente pela vítima. Carrega uma "minhoca" no "anzol". Esta é formada de material do seu próprio corp: e assim sendo, nunca deixa a prêsa morder a isca... Instalado $€ m$ lugar conveniente, deita a minhoca à água e se põe a agitá-la. A vítima se aproxima e tenta agarrar a isca. Com a enorme bôca que possui, faz o peixe pescador enérgica sucção e engole a sua prêsa.

Quem não aprecia o esporte da pesca costuma dizer que a pescaria se pode definir como sendo uma linha com uma minhoca numa das extremidades e um idiota na outra. $O$ autor de tal definição provavelmente nunca pescou. Mesmo aceitando-a, vale a pena ser idiota para pescar. Quem já pescou alguma vez, dificilmente deixará de pescar. Dizem que a emoção ao pegar o prim:ejro peixe é tão grande, que a gente pode até morrer.

Os iaponêses pescam com minhoca, mas sem anzol... Têm prazer em sentir o peixe abocanhar e ingulir a isca. Esse tipo de 
pescaria é tão apreciado, que existe numa das praças de Tóquio um tanque cheio de peixes para êsse fim. Há sempre uma fileira de gente pescando e duas ou mais aguardando uma vaga para poder entrar.

Agora, busquemos nos peixes os fundamentos dos fenômenos psíquicos.

Poderemos falar em vida psíquica de peixes ? Sim, dentro de certos limites. De fato, podemos encontrar nesses animais os primeiros lampejos de uma vida psíquica. E' nos peixes que começamos a aprender muitas das cousas que se passam conosco

Antigamente a ciência tinha a preocupação de mostrar as diferenças entre o homem e os animais. Hoje, pelo contrário, busca encontrar as semelhanças. Para isso, desce do homem para os répteis, para os anfíbios e para os peixes.

A cousa que melhor pode mostrar-nos faculdades psíquicas nos peixes é a conduta dêsses animais na aprendizagem. Há um raciocínio que nos permite reconhecer a priori aquelas faculdades. Muita gente não quer aceitar que os animais tenham inteligência. A opinião comum é que êles só agem pelos instintos.

A Ciência não tem o menor receio de afirmar que os animais possuam inteligência ao lado dos instintos, assim como o homem possui instintos ao lado da inteligência. Uma cousa não exclui a outra. Pelo contrário, ambas se completam. Entre as faculdades humanas e animais só encontramos diferenças de grau. A inteligência animal é da mesma qualidade da inteligência humana. A quantidade é que varia, e dentro de largos limites.

Qual então o raciocínio que nos fará aceitar a inteligência animal antes mesmo de qualquer experimentação? E' o seguinte :

Suponhamos que conhecemos bem a anatomia e a fisiologia humanas. Se capturarmos um animal inteiramente desconhecido, se o dissecarmos e nêle encontrarmos, por exemplo, um coração perfeitamente idêntico ao coração humano, com os mesmos septos, os mesmos compartimentos, os mesmos orifícios, as mesmas válvulas, os mesmos vasos, os mesmos gânglios, enfim. inteiramente estruturado como o coração do homem, acham por ventura os senhores que seria descabida a conclusão que atribuisse a êsse coração as mesmas funções do coração humano ? Não, absolutamente não. A estruturas idênticas correspondem funções idênticas. Porisso, se verificarmos que não sòmente o coração dêsse animal que pela primeira vez estudamos, mas também os pulmões, os rins, o fígado ou seja lá o órgão que fôr, têm a mesma conformação e a mesma estrutura 
dos órgãos idênticos do homem, impõe-se a conclusão de que as respectivas funções são também idênticas. Não há motivo algum para deixarmos de seguir êsse raciocínio ao chegarmos à esfera cerebral. Porisso, se encontrarmos na cabeça de um macaco um cérebro semelhante ao nosso, com os hemisférios constituidos pelos mesmos lóbos, com os lóbos formados pelas mesmas; circunvoluções limitadas pelos mesmos sulcos e com as circunvoluções providas das mesmas áreas motoras e sensoriais, um cérebro enfim com um mesmo córtex cinzento, com a mesma substância branca, as mesmas comissuras, as mesmas áreas de asscciação, poderemos concluir, sem medo de errar, que as mesmas funções conhecidas do cérebro humano devem ser desenvojvidas pelo cérebro daquele macaco. Portanto, o macaco possuidor de um cérebro anatomicamente idêntico ao cérebro humano, deve possuir uma inteligência da mesma qualidade da inteligência humana. Aliás, essas conclusões apriorísticas foram já confirmadas experimentalmente. A psicologia experimental, hoje muito adiantada, dá-nos provas da inteligência animal Os macacos solucionam os problemas que estejam à altura de suas faculdades mentais. Tôda a questão se resume em formular problemas adequados. Não se vai pretender que os macacos sejam capazes de encontrar soluções para problemas formulados para o homem. Bem dosadas, mesmo as baratas resolvem inteligentemente as suas questões.

No domínio dos mamíferos, até do rato, que possui cérebro liso, obtéem-se notáveis respostas. Podemos ensinar o rato a comer conseguindo por meio de uma alavanca uma pílula nutridora que se escapa de um bocal situado na outra extremidade da gaiola. O rato aciona a alavanca e vai apanhar a pílula que a máquina the oferece.

Depois de haverem ensinado individualmente a diversos ratos, os experimentadores resolveram estudar a conduta dos mesmos em coletividade. O resultado foi deveras notável. Nenhum rato tomou a iniciativa de pôr a alavanca em movimento. Talvez cada qual pensasse, que se êle fôsse à alavanca, os outros iriam às pílulas. Afinal um dêles encontra uma solução. Faz o que faríamos nas mesmas condições. Dirige-se à máquina e executa uma série de movimentos com a alavanca e corre para a extremidade oposta, chegando a tempo de colhêr para si algumas pílulas...

Pode-se dar ao rato a idéia exata do tempo. Tem-se para isso uma gaiola ligada ao comedouro por uma ponte eletrificada. A corrente permanece ligada todo o dia, só se interrompendo a determinada hora. Suponhamos ao meio dia. O rato aprende a travessar a ponte a essa hora. $O$ experimentador restabelece a 
ligação depois de um minuto e meio, dando êsse prazo para o rato fazer a sua refeição. Se êle se demorar um pouco mais, ficará preso ou tomará choque. Pois o rato aprende perfeitamente a procurar a comida ao meio dia em ponto, só permanecendo no comedouro pelo espaço de um minuto e meio.

E no domínio dos peixes?

Premiando-se os acêrtos e castigando-se os erros, pode-se ensinar muitas cousas aos peixes. Pode-se, por exemplo, ensinar-lhes a reconhecer as côres. Chegam a distinguir com facilidade diversas tonalidades da mesma côr. Aprendem a passar uma porta quando se acende a luz verde, não o fazendo à luz vermelha.

Aprendem também a distinguir formas, não confundindo um círculo com uma elipse ou um quadrado com um retângulo. Conseguem distinguir o liso do áspero.

$\mathrm{Na}$ esfera auditiva, pode-se ensinar o peixe a procurar o alimento ao som de uma campainha. Possuindo, como se verificou, bua aquidade auditiva que lhe permite distinguir oitavas e até mesmo frações de oitava, o peixe não confunde aquêle som com nenhum outro.

Há em certos laboratórios de psicologia comparativa verdadeiras escolas para peixes. Em alguns casos os peixes aprendem mais depressa quando em grupos. Parece que em coletividade uns estimulam os outros numa espécie de concorrência. Aliás. Isso acontece também na esfera humana. Experiências realizadas nos Estados Unidos com classes homogêneas revelaram que dentro de certos limites, quanto mais numerosas as classes, maior o aproveitamento. Existe qualquer cousa difícil de expljcar mas que se pode com facilidade sentir. Imaginem uma pessôa como a única espectadora num teatro ou num salão de concertos. Talvez nem consiga concentrar-se, podendo até sentir-se mal. Num ambiente repleto, a cousa muda de figura. Parece que há uma disputa dos circunstantes, cada qual querendo apreender e aproveitar mais do que os outros. Com os peixes, se não se passa a mesma cousa, passa-se cousa parecida. Entretanto, há homens, como há peixes, que revelam melhor aprovejtamento nas aulas individuais. A semelhança do que se dá conosco, verificou-se que há peixes que aprendem com mais facilidade do que outros.

Enfim, o que se tem obtido da experimentação com os peixes, parece ir além da expectativa, pois sendo animais providos de hemisférios cerebrais ainda muito primitivos, pouco se esperava conseguir dêles. $O$ que já foi conseguido, porém, basta para podermos inscrevê-los na primeira etapa do desenvolvimento dos fenômenos psíquicos na série dos vertebrados. 